\title{
WALTER GRANGER AND THE HISTORY OF AMERICAN PALEONTOLOGY
}

MORGAN*, Vincent L., The Granger Papers Project, 16 Valentine Hill Road, Durham, NH 03824-3017, U.S.A.; MORGAN, Katherine R., The Granger Papers Project, 16 Valentine Hill Road, Durham, NH 03824-3017, U.S.A.

Walter Granger (1872-1941) played a leading role in American paleontology for nearly fifty years. He began at the American Museum of Natural History in the same month and year, October of 1890, as Henry Fairfield Osborn; Granger, however, came as a seventeen-year-old, country-boy naturalist. While Professor Osborn commenced his research and teaching programs, Granger prepared animal skins and swept Museum floors. Yet long before his death in 1941, and without ever finishing high school, Granger was at the top of his profession as he, Osborn and others created a paleontology department heralded internationally and memorable to this day.

Much of Walter Granger's contribution to American paleontology is based on the many fossil-collecting expeditions he led to Wyoming, New Mexico and other western American states. Granger, however, was also the first American paleontologist to collect fossils from outside the Americas when he spent six months on the continent of Africa in 1907 collecting in El Faiyûm of Egypt. As chief paleontologist and second-incommand of the Central Asiatic Expeditions, Granger was the first from any nation to scientifically collect fossils from the Gobi Desert of Mongolia and from China's Sichuan and Yunnan provinces. Walter Granger first confirmed for Drs. Johann Andersson and Otto Zdansky, during a visit to Zhoukoudian in July of 1921, that the site would yield hominid evidence and advised them on how to excavate for it. This prelimnary site assessment led ultimately to the discovery of Sinanthropus pekinensis (Homo erectus).

Granger's stratigraphic studies, fossil collections, and scientific analyses stemming from his fieldwork in the American West, Africa and Asia still stand as landmarks in vertebrate paleontology. More than one modern-day paleontologist pursues Granger's footsteps with respect and admiration for the seminal quality of his work.

The Granger Papers Project is the exploration of two primary themes: a) the life and work of Walter Granger as an earth scientist; and b) the research and annotation of Granger's unpublished personal diaries, letters, photographs and other material pertaining to his expeditions to the American West, El Faiyûm of Egypt in 1907, China and Mongolia from 1921 to 1930, and to his career at the American Museum of Natural History generally from 1890 to 1941 . Included with Granger's primary source materials are personal diaries by Granger's wife, Anna, who lived and worked in China during much of the Central Asiatic Expeditions and spent time in the field with Granger.

This presentation will illuminate the personality and character of Walter Granger through slides and first-time readings from the Granger papers. It will also discuss the meaning of introducing the Grangers' personal accounts to the existing history of Granger's era. 